\title{
Ionic characterization of the Xingu River water's in the region of the future UHE Belo Monte (PA)
}

\author{
Sidagis-Galli, C. ${ }^{a *}$, Abe, DS. ${ }^{a}$, Rodrigues-Filho, JL. ${ }^{a, b}$, Blanco, FP. ${ }^{a}$, Medeiros, GR. ${ }^{a}$, \\ Faria, CRL. ${ }^{a}$ and Tundisi, JG. ${ }^{a, c}$
}

aAssociação Instituto Internacional de Ecologia e Gerenciamento Ambiental - AIIEGA, Rua Bento Carlos, 750, Centro, CEP 13560-660, São Carlos, SP, Brazil

'Laboratório de Ecologia, Departamento de Engenharia de Pesca, Centro de Educação do Extremo Sul - CERES, Universidade do Estado de Santa Catarina - UDESC, Rua Cel. Fernandes Martins, 270, Progresso, CEP 88790-270, Laguna, SC, Brazil

'Universidade Feevale, Rod. RS 239, 2755, Vila Nova, CEP 93525-075, Novo Hamburgo, RS, Brazil

*e-mail: corina@iie.com.br

Received: July 7, 2015 - Accepted: July 8, 2015 - Distributed: August 31, 2015

(With 1 figure)

The differentiation in the quality of the Amazonian waters is closely related to the geological, geochemical and petrographic aspects of the headwaters of the major rivers (Furch, 1984). The Xingu River is one of the main right bank tributaries of the Amazon Basin and is characterized by having clear and transparent waters. The Xingu basin drains $509,685 \mathrm{~km}^{2}$ of land with basic geological features related to the chemical composition of the water (Stallard and Edmond, 1983) that present clear, transparent, with a small amount of suspended solids, $\mathrm{pH}$ between 4.5 to 7.0. The Xingu River has its origin in pre-Cambrian land and drains crystalline rocks of the Guiana Shield and the Central Plateau of Brazil. The aim of this study was to assess the ionic characteristics of the water in different compartments of the Xingu River in the area of the future UHE Belo Monte during the hydrological periods of flood and drought.

Thirty seven sampling stations were selected in the Xingu River Basin for monitoring the water quality. One sampling station was selected in the upstream portion of the future reservoir; 12 in the future Xingu Reservoir; 5 in the future Intermediary Reservoir that, at this moment, are tributaries of the Xingu River, mainly igarapés; two stations in the Bacajá River; 13 sampling stations in the Volta Grande do Xingu and 4 stations downstream the dam and the Volta Grande do Xingu. All stations were located in backwaters sites and near-shore regions, where conditions are regionally more representative and homogeneous. The water samples were collected during three annual hydrological cycles as part of the "Basic Environmental Project" (PBA) of the Belo Monte Hydroelectric Power Plant (UHE Belo Monte). Two field campaigns were analyzed in each cycle in the following hydrological seasons: March 2012 (flood), September 2012 (dry), April 2013 (flood), October 2013 (dry), April 2014 (flood) and October 2014 (dry). All procedures for sampling, preservation and transportation of the samples were performed according to the APHA (1998). The water samples were analyzed for the dissolved ions concentration (fluoride, chlorine, bromide, nitrate, sulfate, sodium, ammonium, potassium, magnesium, calcium) using liquid chromatography (DIONEX model DX-80), and for total Kjeldahl nitrogen and total phosphorus concentrations using methodologies described in APHA (1998).

The surface water quality in the Xingu River basin showed high spatial heterogeneity, being influenced by the conditions of the surroundings and the areas drained by the water bodies analyzed. In fact, it has long been recognized that aquatic ecosystems are strongly influenced by the landscapes through which they flow (Allan, 2004). The results of the ionic composition of the waters of the Xingu River and its tributaries showed variation between the dry and rainy season (Table 1). In the future Intermediary Reservoir section, formed mainly by streams being barred and Bacajá River, which has a different contribution basin were the sites that had the highest concentrations of fluoride, chloride, sulfate, sodium, potassium, magnesium and calcium in the dry season. The nitrate concentration was higher in the dry period only in the region of the future Intermediary Reservoir $\left(112.52 \pm 88.59 \mu \mathrm{gN} . \mathrm{L}^{-1}\right)$, probably originated from the decomposition of organic matter accumulated in the streams after receding waters of the flood period. The concentrations in the remaining stretches were higher in the rainy season $\left(170.55 \pm 102.30 \mu \mathrm{gN} . \mathrm{L}^{-1}\right.$ in Bacajá River). The concentrations of the major ions $\left(\mathrm{Na}^{+}, \mathrm{K}^{+}, \mathrm{Mg}^{+}\right.$ and $\mathrm{Ca}^{+}$) in the Xingu River were very similar between the dry and the rainy season and the largest differences were observed in the area of the future Intermediary Reservoir and Bacajá River. The total Kjeldahl nitrogen concentrations varied between 0.71 and $1.10 \mathrm{mg} . \mathrm{L}^{-1}$ in the dry season and the highest concentrations were observed in the Bacajá River and the Xingu Reservoir, in the latter mainly by the contribution of streams that run through the city of Altamira (Table 2). In the rainy season the concentrations were slightly higher in the Xingu River, mainly in the downstream $\left(1.14 \mathrm{mg} . \mathrm{L}^{-1}\right)$, indicating that the organic nitrogen supply to the main body originates from the flooded areas and from the soil leaching of the drainage basin. On the other hand, the total phosphorus concentrations were slightly higher in the dry season, 


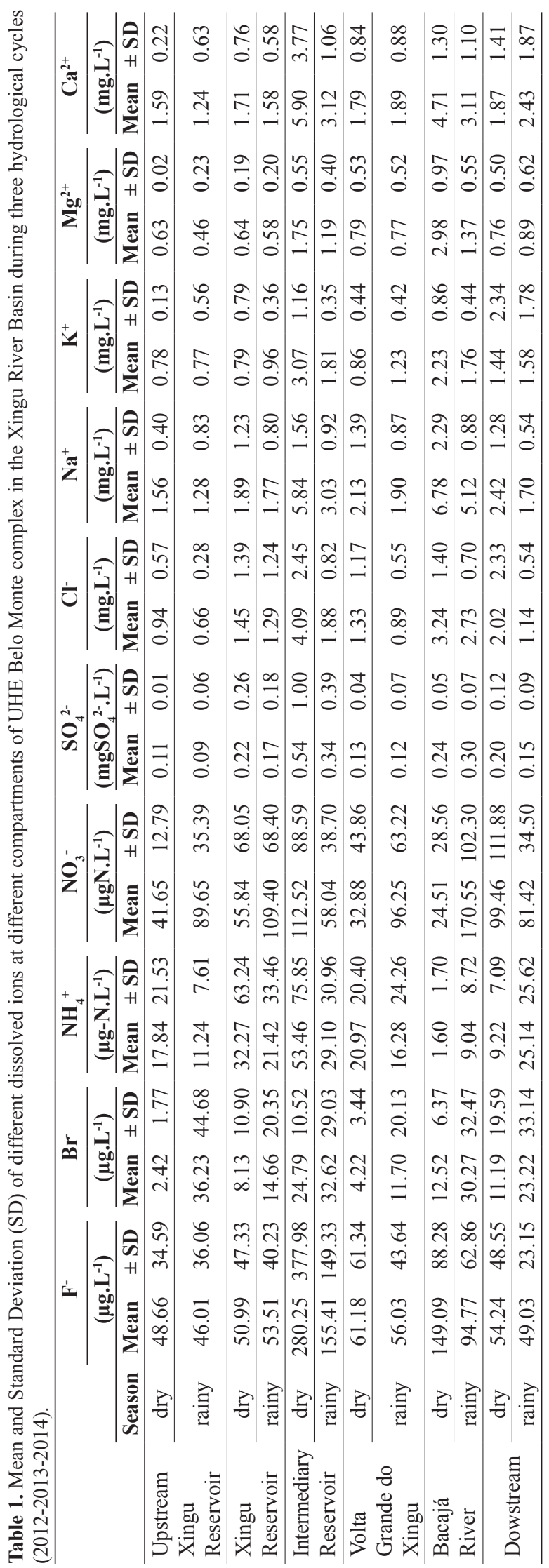


ranging from $22.30 \mu \mathrm{g} . \mathrm{L}^{-1}$ in the upstream of the Xingu Reservoir up to $82.74 \mu \mathrm{g} \mathrm{L}^{-1}$ in the Intermediary Reservoir. These concentrations in the area of the future Intermediary Reservoir were also observed in the rainy season, probably as result of increased particulate $\mathrm{P}$ input by resuspension of the sediment caused by the changes in the river flow and by the runoff of the basin soil into the streams. To highlight the relevance of rainfall or the local lithology in the ionic composition of the waters of the Xingu River and its tributaries was used the Gibbs diagram (Gibbs, 1970). Figure 1 shows the ratio (by weight) $\mathrm{Na} / \mathrm{Na}+\mathrm{Ca}$ and the ratio (by weight) $\mathrm{Cl} / \mathrm{Cl}+\mathrm{HCO}_{3}$ to the total dissolved salts in the water. It can be seen that precipitation is the major natural mechanism controlling surface water chemistry. The Bacajá River and the future Intermediary Reservoir have a little influence of rock weathering.

The Xingu River has a low ion concentration because its waters are originated from the Central Brazilian Shield,

Table 2. Mean and Standard Deviation (SD) of total nitrogen Kjeldahl and total phosphorus at different compartments of UHE Belo Monte complex in the Xingu River Basin during three hydrological cycles (2012-2013-2014).

\begin{tabular}{|c|c|c|c|c|c|c|c|c|c|c|c|}
\hline & \multirow[b]{2}{*}{ Season } & \multicolumn{2}{|c|}{$\begin{array}{c}\text { Conductivity } \\
\left(\mu \mathrm{S} \mathrm{cm}^{-1}\right)\end{array}$} & \multicolumn{2}{|c|}{$\frac{\text { TDS }}{\left(\mathrm{mg}^{-L^{-1}}\right)}$} & \multicolumn{2}{|c|}{$\frac{\mathrm{HCO}_{3}}{\left(\mathrm{mg}^{-\mathrm{L}^{-1}}\right)}$} & \multicolumn{2}{|c|}{$\frac{\text { NTK }}{\left(\mathbf{m g . L ^ { - 1 }}\right)}$} & \multicolumn{2}{|c|}{$\frac{\text { PT }}{\left(\mu \mathrm{g} . \mathrm{L}^{-1}\right)}$} \\
\hline & & Mean & \pm SD & Mean & \pm SD & Mean & \pm SD & Mean & \pm SD & Mean & \pm SD \\
\hline \multirow{2}{*}{$\begin{array}{l}\text { Upstream } \\
\text { Xingu } \\
\text { Reservoir }\end{array}$} & dry & 17.00 & 4.36 & 10.00 & 2.65 & 6.12 & 1.78 & 0.71 & 0.35 & 22.30 & 22.00 \\
\hline & rainy & 14.33 & 0.58 & 9.33 & 0.58 & 7.28 & 3.74 & 0.98 & 0.26 & 19.89 & 2.67 \\
\hline \multirow{2}{*}{$\begin{array}{l}\text { Xingu } \\
\text { Reservoir }\end{array}$} & dry & 20.19 & 12.14 & 11.83 & 7.11 & 6.05 & 2.77 & 0.91 & 1.17 & 40.61 & 32.62 \\
\hline & rainy & 15.42 & 2.89 & 9.81 & 2.05 & 9.13 & 4.51 & 0.66 & 0.49 & 23.32 & 9.04 \\
\hline \multirow{2}{*}{$\begin{array}{l}\text { Intermediary } \\
\text { Reservoir }\end{array}$} & dry & 66.14 & 46.66 & 40.07 & 28.37 & 20.20 & 9.73 & 0.80 & 0.35 & 82.74 & 38.18 \\
\hline & rainy & 30.50 & 10.54 & 19.00 & 6.39 & 15.86 & 7.50 & 0.88 & 0.67 & 66.25 & 36.55 \\
\hline \multirow{2}{*}{$\begin{array}{l}\text { Volta Grande } \\
\text { do Xingu }\end{array}$} & dry & 24.56 & 17.39 & 15.09 & 13.44 & 8.32 & 6.04 & 0.75 & 0.55 & 35.65 & 17.89 \\
\hline & rainy & 16.52 & 4.78 & 10.21 & 3.08 & 8.66 & 4.54 & 0.84 & 0.59 & 22.74 & 11.89 \\
\hline \multirow{2}{*}{ Bacajá River } & dry & 75.67 & 14.47 & 43.67 & 8.45 & 25.06 & 6.46 & 1.10 & 0.47 & 47.46 & 15.58 \\
\hline & rainy & 37.17 & 3.60 & 23.33 & 2.25 & 18.73 & 5.64 & 0.42 & 0.38 & 48.14 & 7.24 \\
\hline \multirow{2}{*}{ Dowstream } & dry & 25.45 & 23.83 & 15.27 & 13.93 & 7.63 & 5.33 & 0.76 & 0.34 & 30.83 & 7.65 \\
\hline & rainy & 15.25 & 6.27 & 10.50 & 4.85 & 7.88 & 3.48 & 1.14 & 0.95 & 26.82 & 18.24 \\
\hline
\end{tabular}
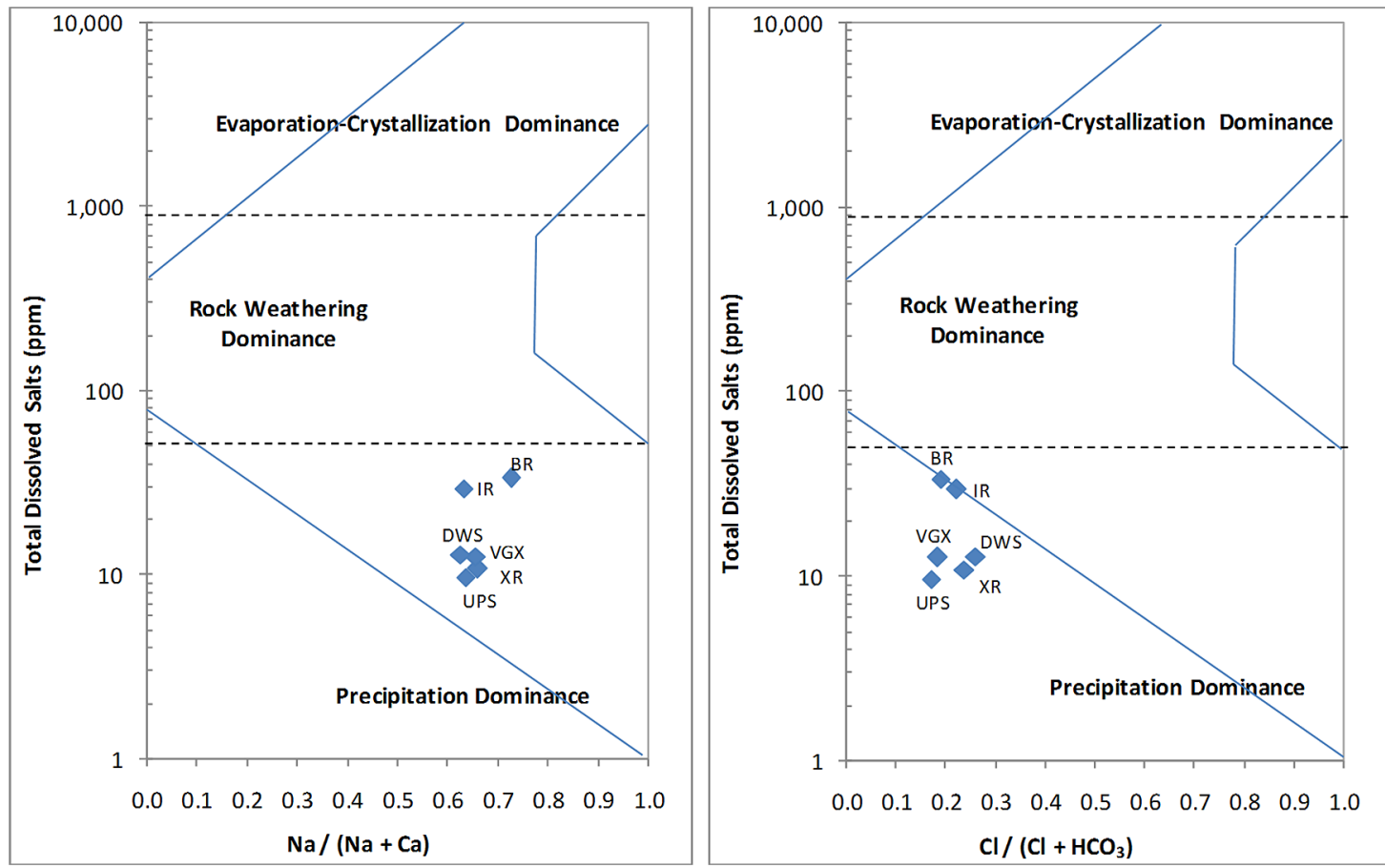

Figure 1. Gibbs diagrams showing the most likely process responsible for hydrochemistry of the Xingu River Basin during three hydrological cycles (2012-2013-2014). XR: Xingu Reservoir; UPS: Upstream Xingu Reservoir; VGX: Volta Grande do Xingu; DWS: Downstream; IR: future Intermediary Reservoir; BR: Bacajá River. 
which is composed by geochemically poor Precambrian rocks (granite and gneissin) and by the fact that the basin has stable processes of erosion and sedimentation (Sioli, 1984). The differences observed between the area of future Intermediary Reservoir, the Bacajá River and the main body of the Xingu River indicate that, although belonging to the same basin, the different portions of the Xingu River and its tributaries have different chemical characteristics, influenced by both the lithology of the drainage basins and the existing local anthropogenic impacts. Most sampling stations monitored in the UHE Belo Monte complex on the Xingu River and tributaries showed good water quality in terms of ionic concentration and nutrients (TKN and PT) due to the absence of major local impact and to the high depuration capacity of the Xingu River. The results also show the importance of the connectivity of the tributaries of Xingu River with the main river. Tributaries collect organic matter from the watersheds and the surrounding forest contributing thus for the chemical composition of Xingu River water (Tundisi and Matsumura Tundisi, 2013). Furch (1984), discussing the composition of the Amazonian water bodies, emphasizes that only the waters that originates from the geochemistry of the waters in the west peripherical amazonian region such as the Solimões River and várzeas lakes are classified as carbonate waters. The remaining waters such as Xingu River are on the range of low carbonate. Also when compared with the average ionic composition of river waters in different continents (mg.L $\mathrm{L}^{-1}$ ) (from Payne, 1986), Xingu waters shows very low calcium ion composition.

\section{References}

ALLAN, JD., 2004. Landscapes and riverscapes: the influence of land use on stream ecosystems. Annual Review of Ecology Evolution and Systematics, vol. 35, no. 1, p. 257-284. http:// dx.doi.org/10.1146/annurev.ecolsys.35.120202.110122.

American Public Health Association - APHA, 1998. Standard methods for the examination of water and wastewater. Washington: APHA/AWWA/WPCF.

FURCH, K., 1984. Water chemistry of the Amazon basin: the distribution of chemical elements among freshwaters. In SIOLI, H. (Ed.). The Amazon: limnology and landscape ecology of a mighty tropical river and its basin. Dordrecht: Dr. W. Junk Publishers. p. 167-199. Chapter 6. Monographiae Biologicae, vol. 56

GIBBS, RJ., 1970. Mechanism controlling world water chemistry. New York: Science. p. 1088-1090. New Series, vol. 170, no. 3962.

PAYNE, AI., 1986. The ecology of tropical lakes and rivers. New York: John Wiley \& Sons.

SIOLI, H., 1984. The Amazon: Limnology and landscape ecology of a mighty tropical river and its basin. Dordrecht: Dr. W. Junk Publishers. p. 762. Monographiae Biologicae, vol. 56.

STALLARD, RF. and EDMOND, JM., 1983. Geochemistry of the Amazon basin: 2. The influence of the geology and weathering environment on the dissolved load. Journal of Geophysical Research. vol. 88, no. C14, p. 9671-9688.

TUNDISI, JG. and MATSUMURA TUNDISI, T., 2013. Limnologia. São Paulo: Oficina de Textos. p. 631. 